Supporting Information

\title{
Improvement of Lithium Metal Polymer Batteries through a Small Dose of Fluorinated Salt
}

Alexander Santiago, ${ }^{\dagger}$ Xabier Judez,,$+\hbar$ Julen Castillo, ${ }^{\dagger, *}$ Iñigo Garbayo, ${ }^{\dagger}$ Amaia Sáenz de Buruaga, ${ }^{\dagger}$ Lixin Qiao, ${ }^{\dagger,}$, Giorgio Baraldi, ${ }^{\dagger}$ José Antonio Coca-Clemente, ${ }^{\dagger}$ Michel Armand, ${ }^{\dagger}$ Chunmei Li, ${ }^{*} \dagger$ and Heng Zhang $*, \dagger$

${ }^{\dagger}$ Centre for Cooperative Research on Alternative Energies (CIC energiGUNE), Basque Research and Technology Alliance (BRTA), Alava Technology Park, Albert Einstein 48, 01510 Vitoria-Gasteiz, Spain

¥ University of the Basque Country UPV-EHU, P.P. Box 644, 48080 Bilbao, Spain

AUTHOR INFORMATION

Corresponding Author

*C.L.: E-mail: cli@cicenergigune.com.

*H.Z.: E-mail: hzhang@cicenergigune.com. 


\section{Experimental}

\section{Preparation of polymer electrolyte membrane}

A typical solvent casting method, coupled with a hot-pressing of high temperature controller film maker, was used to prepare the polymer electrolyte membranes. The thickness average of the resulting membranes was around $50 \mu \mathrm{m}$. In order to obtain the electrolytes, a pre-determined quantity of battery grade Li-salts [LiTCM and LiFSI (Provisco)] was dissolved in an optimized amount of acetonitrile solvent and after, the corresponding amount of PEO (5 million of molecular weight, Sigma-Aldrich) was added. The mixture was stirred until complete dissolution of the polymer compound. The salt concentration was fixed to a molar ratio of 20:1 (EO/Li $=20)$.

\section{Thermal behavior}

The phase transitions of the as-prepared LiTCM/PEO and LiTCM-LiFSI/PEO electrolytes were characterized by differential scanning calorimeter (DSC) (Q2000, TA Instruments). The samples (ca. 5-10 mg) were hermetically sealed in an aluminium crucible before the measurement. The employed protocol involved two consecutive scans at a cooling and heating rate of $10{ }^{\circ} \mathrm{C} \min ^{-1}$ in the temperature range of -80 to $150{ }^{\circ} \mathrm{C}$. An isothermal step for 5 minutes was made at the two extreme temperatures, low $\left(-80^{\circ} \mathrm{C}\right)$ and high $\left(150^{\circ} \mathrm{C}\right)$ of each scan.

The thermogravimetric analysis (TGA) was performed on a TGA 209 F1 Libra (Netzsch). The samples were heated from room temperature (RT) to $550{ }^{\circ} \mathrm{C}$ at a heating rate of $10{ }^{\circ} \mathrm{C} \mathrm{min}^{-1}$ under Argon flow. 


\section{Ionic conductivity}

The ionic conductivities of the polymer electrolytes were evaluated by AC impedance spectroscopy (VMP3 potentiostat, Biologic) with signal amplitude of $10 \mathrm{~mA}$ over the frequency range of $10^{-1}$ to $10^{6} \mathrm{~Hz}$. The configuration used for the experiments was a CR2032 type coin cell using two stainless steel (SS) blocking electrodes (SS | SPEs | SS) assembled in an Argon filled glovebox.

\section{Anodic stability}

The electrochemical stability of the polymer electrolytes was investigated using a linear sweep voltammogram (LSV) (VMP3 potentiostat, Biologic) making use of a two electrode set up at $70{ }^{\circ} \mathrm{C}$. While stainless steel with a surface area of $0.07 \mathrm{~cm}^{2}$ was used as a working electrode, $\mathrm{Li}^{\mathrm{o}}$ disk served as both counter and reference electrodes. The $\mathrm{Li}^{\circ} \mid$ SPEs $\mid$ SS coin-type cell configuration was tested over a wide range potentials from the open circuit potential $(\mathrm{OCP})$ to $6.0 \mathrm{~V} \mathrm{vs} . \mathrm{Li}^{\circ} / \mathrm{Li}^{+}$at a scan rate of $1 \mathrm{mV} \mathrm{s}^{-1}$ at $70{ }^{\circ} \mathrm{C}$.

\section{Electrochemical stability of electrolyte/L $i^{\circ}$ electrode}

The compatibility of the mixture of LiTCM with LiFSI both in solid polymer electrolytes (SPE, using PEO as polymer matrix) and liquid electrolytes (LEs, using DME as solvent) with $\mathrm{Li}^{\circ}$ electrode was investigated utilizing symmetrical $\left(\mathrm{Li}^{\circ} \mid \mathrm{SPEs}\right.$

$\left.\left|\mathrm{Li}^{\circ} ; \mathrm{Li}^{\circ}\right| \mathrm{LEs} \mid \mathrm{Li}^{\circ}\right)$ coin cells, which were assembled in an argon-filled glove box. The galvanostatic cycling of the $\mathrm{Li}^{\circ}$ symmetric cells was evaluated using a Maccor Battery Tester (Series 4000). The $\mathrm{Li}^{\circ}$ symmetric cells were cycled galvanostatically at 
a current density of $0.1 \mathrm{~mA} \mathrm{~cm}{ }^{-2}$, wherein the duration of each half-cycle was $2 \mathrm{~h}$. The temperature of the cycling was fixed at $70^{\circ} \mathrm{C}$ for the PEO-based electrolytes and at room temperature $\left(23 \pm 2{ }^{\circ} \mathrm{C}\right)$ for the liquid ones.

\section{Surface morphology and composition of $L i^{\circ}$ deposits}

The surface morphologies and microstructures of the $\mathrm{Li}^{\circ}$ deposits were examined by the galvanostatic deposition of $\mathrm{Li}^{\circ}$ on $\mathrm{Cu}$ substrates making use of $\mathrm{Li}^{\circ} \mid$ DME-based LEs $\mid \mathrm{Cu}$ cells at a current density of $0.1 \mathrm{~mA} \mathrm{~cm}^{-2}$ for 20 hours at room temperature. $\mathrm{Li}^{\circ}$ surface morphology was studied using field emission scanning electron microscope (Quanta 200 FEG, FEI). X-ray photoelectron spectroscopy (XPS) was used to determine the chemical composition of the surface layers formed upon cell cycling. A SPCES Phoibos 150 spectrometer with nonmonochromatic $\mathrm{Mg} \mathrm{K \alpha}$ source $(h v=1253.6 \mathrm{eV})$. The spectra were recorded with high resolution scans at low power (100 W, $20 \mathrm{eV}$ pass energy, and $0.1 \mathrm{eV}$ energy step) was employed. The calibration of the binding energy was performed taking into account as reference the graphitic signal at $284.4 \mathrm{eV}$. The samples were cleaned with DME and dried thoroughly under vacuum before transferred to the SEM or XPS chamber by a home-designed airtight setup.

\section{$\mathrm{LiFePO}_{4}$ cathode preparation}

$63 \mathrm{wt} \%$ lithium iron phosphate $\left(\mathrm{LiFePO}_{4}\right), 7 \mathrm{wt} \%$ conductive carbons $(\mathrm{C}-65)$, and 30 $\mathrm{wt} \% \mathrm{LiTCM} / \mathrm{PEO}$ as catholyte were used to prepare $\mathrm{LiFePO}_{4}$ cathodes. The mass loading of $\mathrm{LiFePO}_{4}$ was found to be around $6 \mathrm{mg} \mathrm{cm}{ }^{-2}$ (areal capacity: $0.9 \mathrm{mAh} \mathrm{cm}$ $\left.{ }^{2}\right)$. 
Cycling of $\mathrm{Li}^{\circ} \| \mathrm{LiFePO}_{4}$ cells

The cells were assembled in an Argon filled glovebox using the vacuum dried $\mathrm{LiFePO}_{4}$ electrode as cathode, PEO-based electrolyte membrane as both electrolyte and separator, and $\mathrm{Li}^{\circ}$ disk (China Energy Lithium) as anode. The cells were then cycled galvanostatically at a constant current (CC) mode between 2.5 and $3.7 \mathrm{~V}$ vs. $\mathrm{Li}^{\circ} / \mathrm{Li}^{+}$at $70{ }^{\circ} \mathrm{C}$ using a Maccor Battery Tester (Series 4000).

Table S1. Atomic percentage of the elements on the surface of $\mathrm{Li}^{\circ}$ deposits obtained from different electrolytes (values estimated from the quantitative analysis of the survey spectra).

\begin{tabular}{lcccccc}
\hline Sample & $\mathrm{Li} / \%$ & $\mathrm{C} / \%$ & $\mathrm{~N} / \%$ & $\mathrm{O} / \%$ & $\mathrm{~F} / \%$ & $\mathrm{~S} / \%$ \\
\hline LiTCM/DME + LiFSI & 22.12 & 45.58 & 11.95 & 15.39 & 2.45 & 2.51 \\
LiTCM/DME & 18.50 & 49.56 & 20.24 & 11.70 & & \\
\hline
\end{tabular}




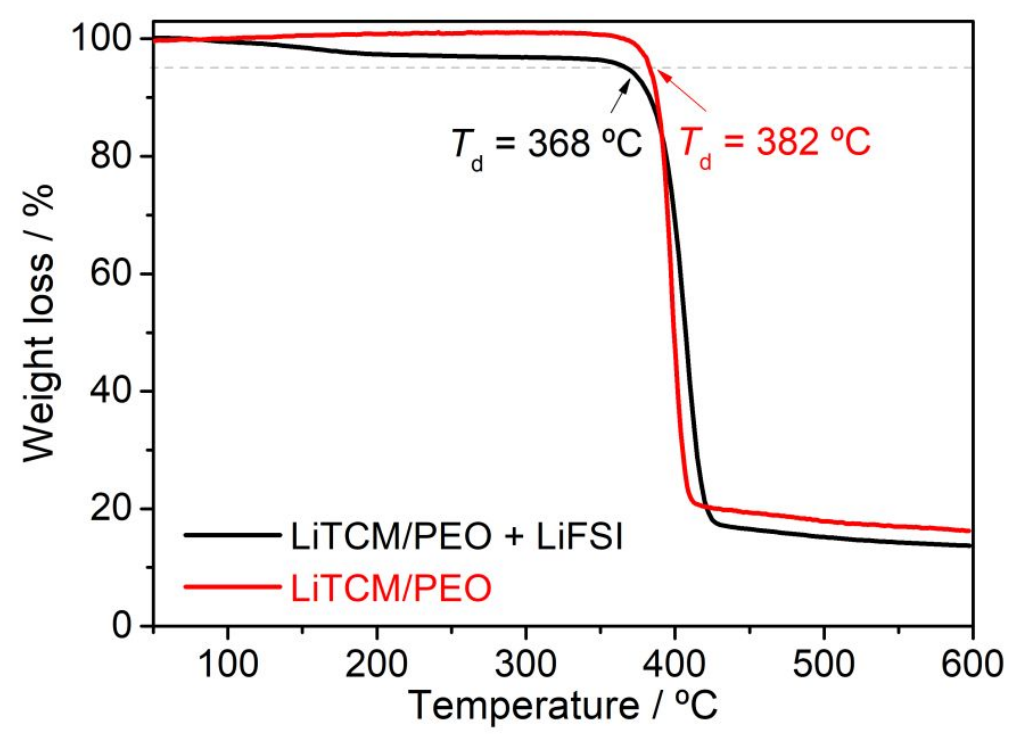

Figure S1. TGA thermograms for the as-prepared polymer electrolytes.

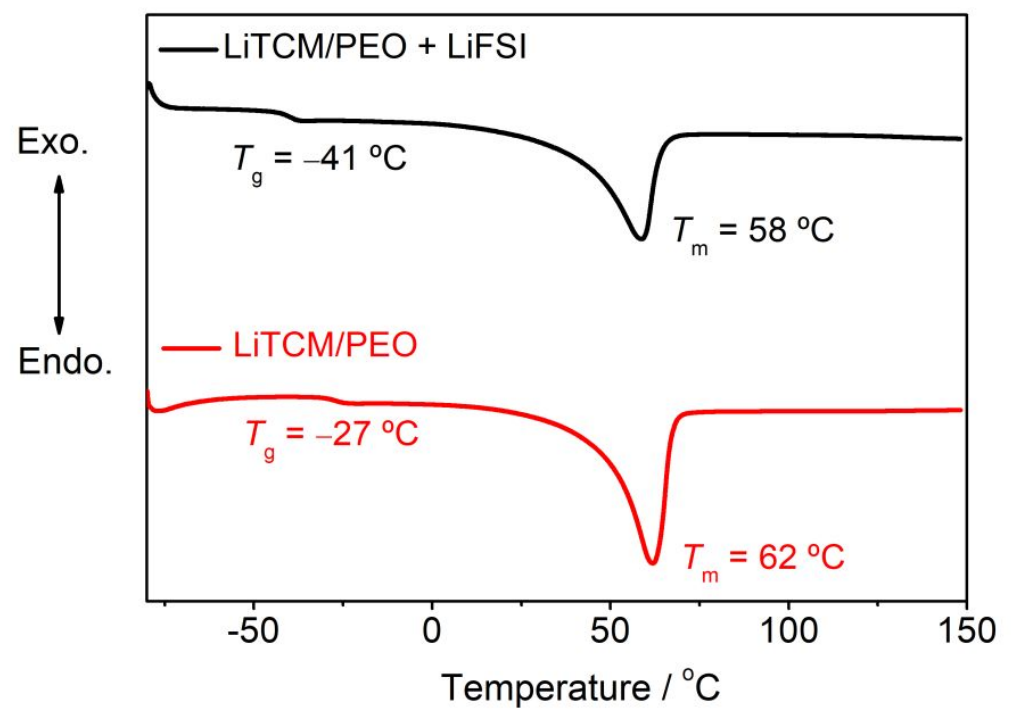

Figure S2. DSC traces of the as-prepared polymer electrolytes 


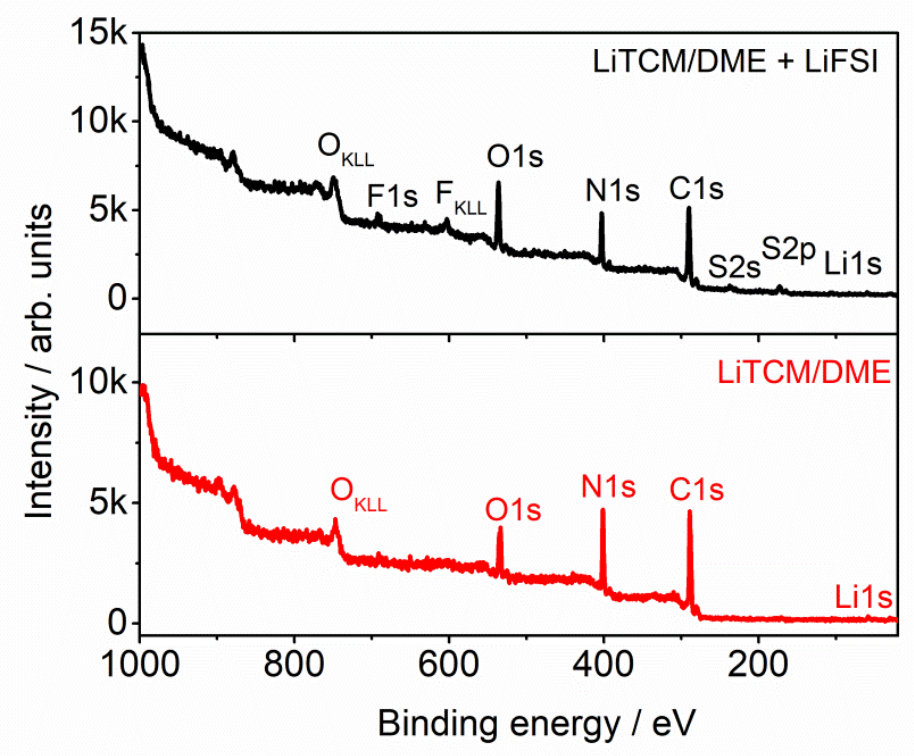

Figure S3. XPS survey spectra of $\mathrm{Li}^{\circ}$ deposits on $\mathrm{Cu}$ current collector after cycling with LiTCM/DME + LiFSI and LiTCM/DME electrolytes.

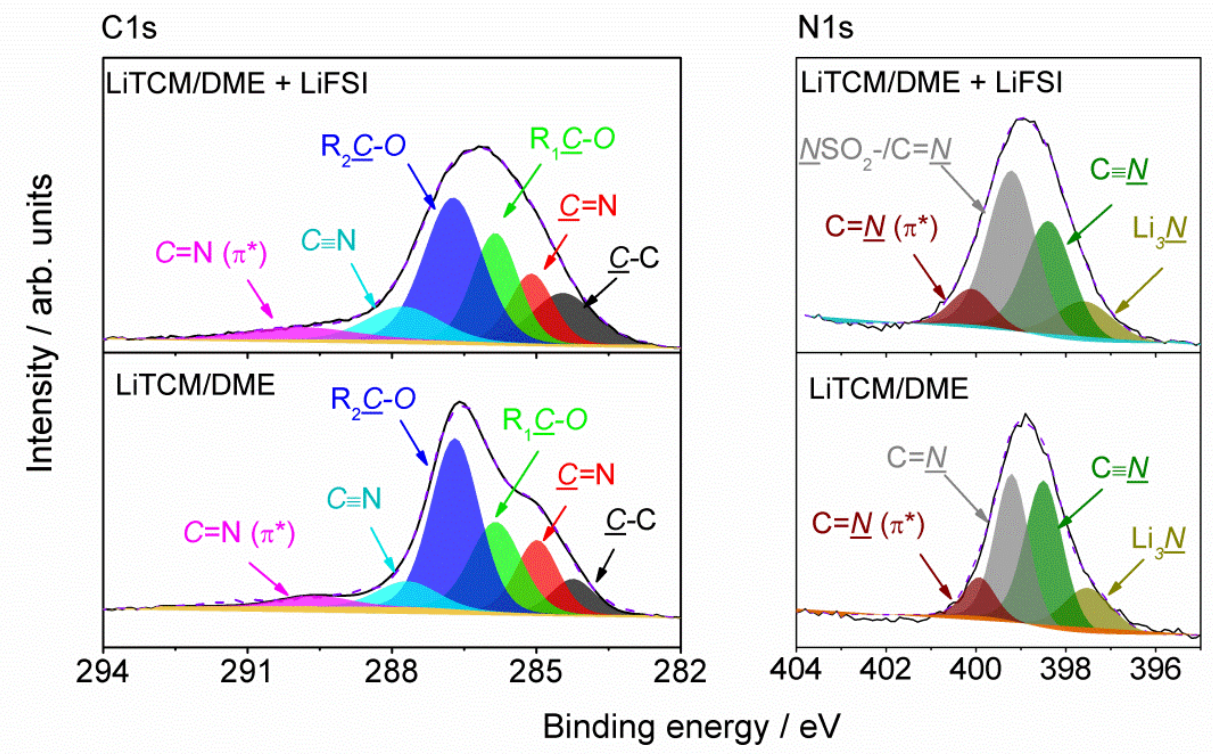

Figure S4. XPS spectra corresponding to $\mathrm{C} 1 \mathrm{~s}$ and $\mathrm{N} 1 \mathrm{~s}$ regions of $\mathrm{Li}^{\circ}$ deposits on $\mathrm{Cu}$ current collector afyer cycling with LiTCM/DME + LiFSI and LiTCM/DME electrolytes. Solid line (black) and dash line (purple) represent experimental and fitted data, respectively. $\mathrm{R}_{1} \underline{C}-\mathrm{O}$ and $\mathrm{R}_{2} \underline{C}-\mathrm{O}$ correpond to $\underline{C}_{3}-\mathrm{O}$ and $-\mathrm{H} \underline{C}-\mathrm{O}-\mathrm{C}-$, respectively ${ }^{1}$. 
(a)

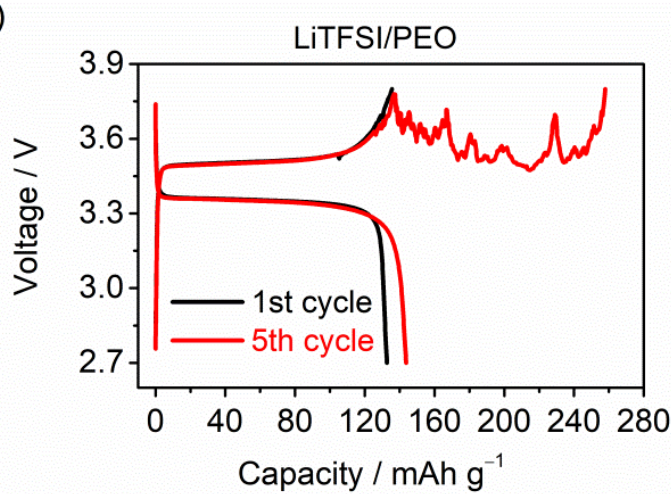

(b)

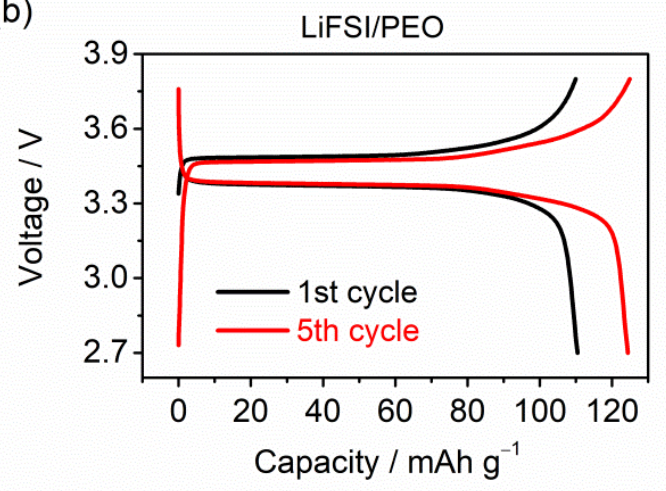

(c)

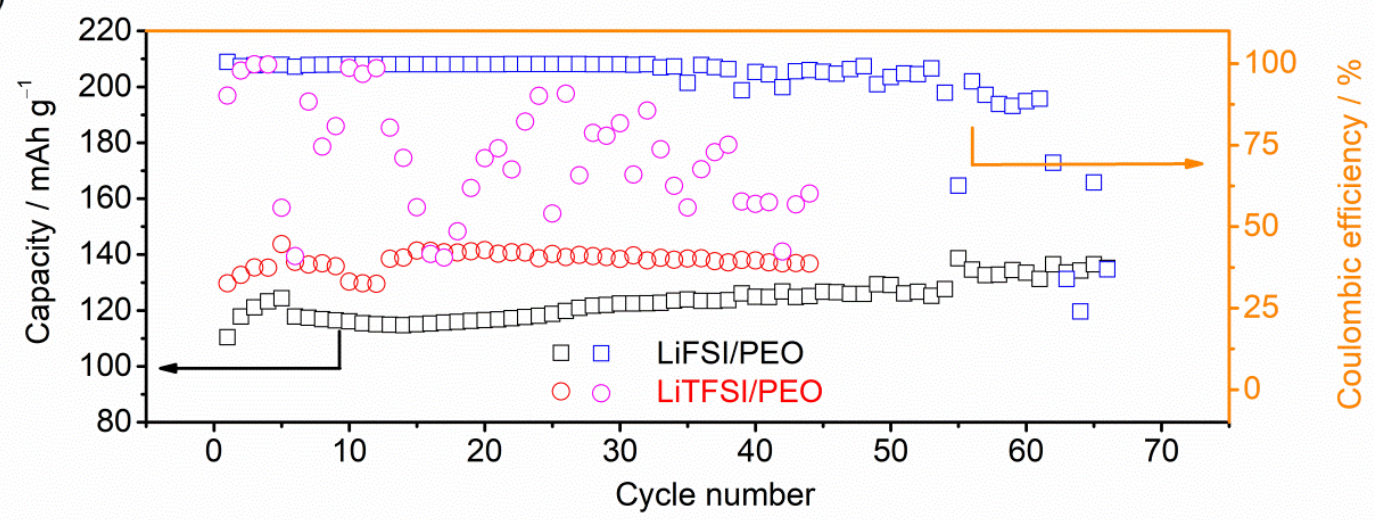

Figure S5. Cycling performance of $\mathrm{Li}^{\circ} \| \mathrm{LiFePO}_{4}$ cells at $70{ }^{\circ} \mathrm{C}$. Charge/discharge profiles of the cells using the references (a) LiTFSI//PEO, and (b) LiFSI/PEO. (c) Specific capacity and Coulombic efficiency vs. cycle number using a C-rate of $\mathrm{C} / 5$ for the first 5 cycles and $\mathrm{C} / 3$ for the subsequent ones.

\section{References}

1. Zhang, H.; Judez, X.; Santiago, A.; Martinez-Ibañez, M.; Muñoz-Márquez, M. Á.; Carrasco, J.; Li, C.; Eshetu, G. G.; Armand, M. Fluorine-Free Noble Salt Anion for High-Performance All-Solid-State Lithium-Sulfur Batteries. Adv. Energy Mater. 2019, 9 (25), 1900763. https://doi.org/10.1002/aenm.201900763. 